\title{
MODELING AND SIMULATION BASED ON THE CONSTITUTIVE EQUATION OF 25Cr2Ni4MoV STEEL FOR A SUPER-LARGE NUCLEAR-POWER ROTOR
}

\author{
MODELIRANJE IN SIMULACIJA KONSTITUTIVNE ENAČBE \\ JEKLA 25Cr2Ni4MoV ZA ZELO VELIK ROTOR V JEDRSKI \\ ELEKTRARNI
}

\author{
Li-yan Ye, Yue-wen Zhai*, Le-yu Zhou, Peng Jiang \\ Beijing Research Institute of Mechanical and Electrical Technology, Science and Technology Development and Innovation Center, \\ 18 Xueqing Road, Haidian District, Beijing 100083, P.R. China \\ Prejem rokopisa - received: 2019-06-26; sprejem za objavo - accepted for publication: 2019-08-18
}

doi:10.17222/mit.2019.136

The constitutive equation of the $25 \mathrm{Cr} 2 \mathrm{Ni} 4 \mathrm{MoV}$ steel for a super-large nuclear-power rotor was studied using compression experiments within a temperature range of $1373-1523 \mathrm{~K}$ and a strain rate range of $0.001-0.1 \mathrm{~s}^{-1}$ on a Gleeble-1500 thermal-mechanical simulation tester. Considering the application of the constitutive equation in a finite-element (FE) software, the linear-interpolation method incorporated in the FE software and the strain-compensated Arrhenius model were used to predict the flow stress of the $25 \mathrm{Cr} 2 \mathrm{Ni} 4 \mathrm{MoV}$ steel. It was found that the Arrhenius model was stronger in estimating the flow behavior compared to the linear-interpolation method. By means of user subroutines, the Arrhenius model was integrated into FE software DEFORM to simulate the isothermal compression. The comparison between the simulated and theoretical results confirmed the validity of the Arrhenius model.

Keywords: 25Cr2Ni4MoV, strain-compensated Arrhenius model, linear interpolation, high-temperature flow behavior

Konstitutivno enačbo za jeklo $25 \mathrm{Cr} 2 \mathrm{Ni} 4 \mathrm{MoV}$, ki se uporablja za izdelavo zelo velikega rotorja jedrske elektrarne, so avtorji prispevka analizirali z uporabo eksperimentalnih podatkov tlačnih preizkusov, dobljenimi v temperaturnem območju med $1373 \mathrm{~K}$ in $1523 \mathrm{~K}$, in $\mathrm{v}$ področju hitrosti deformacij med $0,001 \mathrm{~s}^{-1}$ in $0,1 \mathrm{~s}^{-1}$, na termomehanskem simulatorju Gleeble 1500 . Upoštevajoč uporabo konstitucijske enačbe $\mathrm{v}$ programskem orodju na osnovi metode končnih elementov (FE) v katerega so uvedli metodo linearne interpolacije in uporabili deformacijsko kompenzirani Arrheniusov model za krivulje tečenja jekla $25 \mathrm{Cr} 2 \mathrm{Ni} 4 \mathrm{MoV}$. Ugotovili so, da je Arrheniusov model boljši za oceno tečenja, kot metoda linearne interpolacije. V uporabniški podprogram orodja DEFORM-FE so integrirali Arrheniusov model za simulacijo izotermne kompresije (obremenjevanja pod tlakom). Primerjava med na simulatorju dobljenimi in teoretičnimi rezultati je potrdila veljavnost Arrheniusovega modela.

Ključne besede: jeklo 25Cr2Ni4MoV, deformacijsko kompenzirani Arrheniusov model, linearna interpolacija, obnašanje materiala med tečenjem (tlačno plastično deformacijo) pri visokih temperaturah

\section{INTRODUCTION}

The material-development history of super-large nuclear-power rotors includes 34CrNi3Mo, $2 \% \sim 4 \% \mathrm{NiCrMoV}, 30 \mathrm{Cr} 2 \mathrm{Ni} 4 \mathrm{MoV}$ and $25 \mathrm{Cr} 2 \mathrm{Ni} 4 \mathrm{MoV} .{ }^{1-4}$ With a decrease in the carbon and impurity content, $25 \mathrm{Cr} 2 \mathrm{Ni} 4 \mathrm{MoV}$ has a good balance of toughness, strength and corrosion resistance in a severe service environment. Therefore, $25 \mathrm{Cr} 2 \mathrm{Ni} 4 \mathrm{MoV}$ has a great potential for super-large nuclear-power rotors. A superlarge nuclear-power rotor is forged with a hydraulic press at a high temperature from a large cast ingot of about $650 \mathrm{t}$, which is known for its high cost, small amount and long production cycle, and for which it is difficult to obtain the optimum hot-forming process parameters through a practical production. A finiteelement simulation provides us with an effective tool for obtaining the optimum process parameters by predicting the deformation behavior of metals and alloys; it does

*Corresponding author's e-mail:

yeliyan2006@sina.com (Yue-wen Zhai) not only guide the practical production, but can also decrease the cost. The constitutive equation, which plays an important role in predicting the flow stress, selecting the press load and designing the forming process, is crucial in an FE simulation. However, the research about the constitutive equation of $25 \mathrm{Cr} 2 \mathrm{Ni} 4 \mathrm{MoV}$ is seldom reported.

Considering the application of a constitutive equation in a finite-element analysis, the phenomenological constitutive model is widely used to predict the flow stress at elevated temperatures due to its fewer material constants, which can be obtained with uniaxial hot-compression tests. ${ }^{5}$ The strain-compensated Arrhenius model is one kind of the commonly used phenomenological model. L. $\mathrm{Xu}$ and $\mathrm{L}$. Chen ${ }^{6}$ reported on the strain-compensated Arrhenius model that exhibited accuracy when predicting the flow stress of the $25 \mathrm{Cr} 3 \mathrm{Mo} 3 \mathrm{NiNb}$ steel. Y. Zhang and H. L. Sun ${ }^{7}$ established the strain-compensated Arrhenius model for the Cu-Zr-Nd alloy. L. Chen and G. Q. Zhao ${ }^{8}$ found two appropriate Arrhenius-type constitutive equations for the 7005 aluminum alloy. Y. F. Li 
Table 1: Chemical composition of steel $25 \mathrm{Cr} 2 \mathrm{Ni} 4 \mathrm{MoV}$ (in mass fractions, $(w / \%)$

\begin{tabular}{|c|c|c|c|c|c|c|c|c|c|c|}
\hline $\mathrm{C}$ & $\mathrm{Mn}$ & $\mathrm{P}$ & $\mathrm{S}$ & $\mathrm{Si}$ & $\mathrm{Ni}$ & $\mathrm{Cr}$ & $\mathrm{Mo}$ & $\mathrm{V}$ & $\mathrm{Cu}$ & $\mathrm{Fe}$ \\
\hline $\mathrm{F} \leq 0.3$ & $0.1 \sim 0.3$ & $\leq 0.015$ & $\leq 0.015$ & $\leq 0.012$ & $2.0 \sim 2.5$ & $2.15 \sim 2.45$ & $0.6 \sim 0.85$ & $\leq 0.12$ & $\leq 0.17$ & $\mathrm{Bal}$. \\
\hline
\end{tabular}

and Z. H. Wang ${ }^{9}$ proposed an Arrhenius-type constitutive equation for the V-5Cr-5Ti alloy. A. Abbasi Bani and A. Z. Hanzaki ${ }^{10}$ studied Arrhenius-type equations for the Mg-6Al-1Zn alloy. However, integrating a strain-compensated Arrhenius model into the FE software was seldom reported.

Three methods can be used to input a constitutive equation into the FE software. The first one involves the use of the coefficients and constants of the material model provided by the FE software. The second one requires the definition of the flow stress presented in the tabular data format. The third one involves the building of flow-stress models using user-defined flow-stress subroutines. However, regarding the first method, the flow-stress models supported by the FE software are not applicable to all metals and alloys. For the second method, the stress-strain curves at different deformation conditions are obtained with linear interpolation based on the data table, which means that the accuracy of the material model is not guaranteed. Therefore, the third method based on programming the relationships between stress, strain, strain rate and temperature with the FE software using a user routine is recommended, as it does not only simulate the constitutive equation that is not available in the material library of the FE software, but can also accurately predict the flow behavior of metals and alloys.

In this paper, the hot-deformation behavior of $25 \mathrm{Cr} 2 \mathrm{Ni} 4 \mathrm{MoV}$ was investigated using compression tests with different temperatures and strain rates. Both the strain-compensated Arrhenius model and linear-interpolation method were used to predict the flow stresses, and the prediction precision of the models was assessed using standard statistical parameters. By integrating the Arrhenius model into the FE software, hot compressions were simulated.

\section{EXPERIMENTAL PART}

The chemical composition of the $25 \mathrm{Cr} 2 \mathrm{Ni} 4 \mathrm{MoV}$ steel is shown in Table 1. Compression specimens with a diameter of $8 \mathrm{~mm}$ and length of $12 \mathrm{~mm}$ were machined. The materials were provided by Sinomach-he Co, Ltd and the initial grain size was $24.22 \mu \mathrm{m}$. Before the compression, the specimens were first heated to $1523 \mathrm{~K}$ at a heating rate of $10 \mathrm{~K} / \mathrm{s}$ and dwell time of $5 \mathrm{~min}$ to
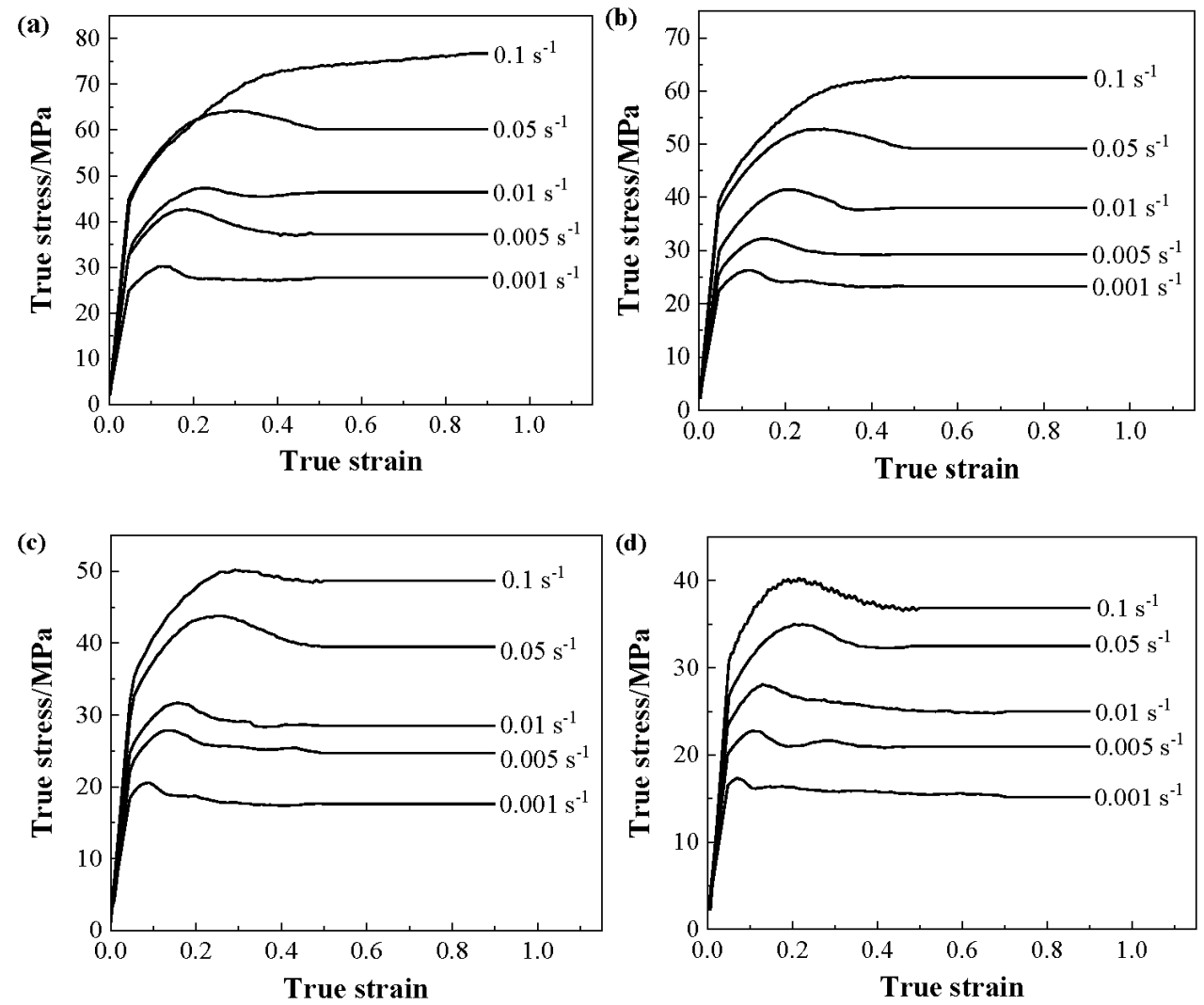

Figure 1: True-stress-strain curves obtained at different temperatures: a) $1373 \mathrm{~K}$, b) $1423 \mathrm{~K}$, c) $1473 \mathrm{~K}$, d) $1523 \mathrm{~K}$ 
achieve a homogeneous austenitic microstructure, then cooled down to the deformation temperature at a rate of $10 \mathrm{~K} / \mathrm{s}$ and dwell time of $1 \mathrm{~min}$. In order to minimize the effect of friction, graphite sheets used as the lubricant material were applied to both ends of the specimens. Hot-compression tests with four different temperatures $(1373,1423,1473$, and 1523) $\mathrm{K}$ and five strain rates $(0.001,0.005,0.01,0.05,0.1) \mathrm{s}^{-1}$ at a true strain of $90 \%$ were performed on a Gleeble-1500 thermal-mechanical simulator.

\section{RESULTS AND DISCUSSION}

\subsection{Flow behavior}

Figure 1 shows a number of stress-strain curves obtained during the compression tests. It can be found that the flow stress increases with the increased strain rate when the deformation temperature is fixed, or that the flow stress decreases with the increased deformation temperature when the strain rate remains unchanged. For most deformation conditions, stress-strain curves have the characteristics of a dynamic recrystallization (DRX) with a single peak. In the initial stage of the forming process, the flow stress rapidly reaches the peak value. This is because the work-hardening rate induced by dislocation intersections and pileups is higher than the softening rate induced by dynamic recovery (DRV). Then the flow stress decreases due to the dominant softening rule of DRX. Finally, the stress reaches a steady state when the equilibrium of work softening and work hardening is obtained. At deformation conditions
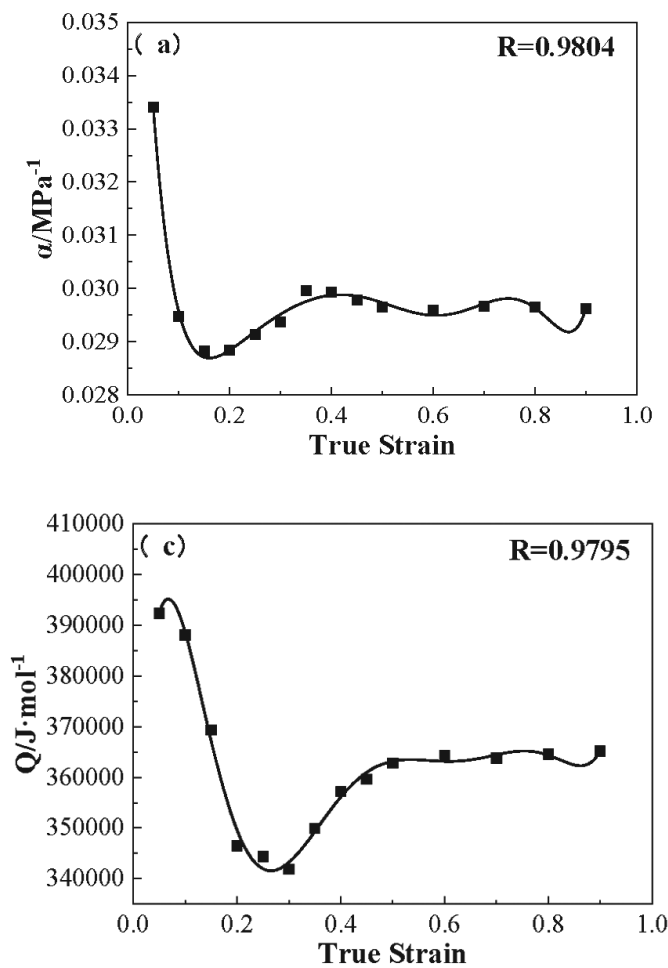

of $1373 \mathrm{~K} / 0.1 \mathrm{~s}^{-1}$ and $1423 \mathrm{~K} / 01 \mathrm{~s}^{-1}$, the stress keeps increasing or remains constant, indicating a dynamic recovery as well as a dynamic recrystallization, lasting until the end of the deformation process.

\subsection{Strain-compensated Arrhenius-type constitutive model}

\subsubsection{Establishment of the constitutive equation}

For the high-temperature deformation, the Arrhenius model and Zener-Hollomon $(Z)$ model are widely used to describe the relationship between the peak stress, deformation temperature and strain rate. ${ }^{11-13}$

$$
Z=\dot{\varepsilon} \exp \left(\frac{Q}{R T}\right)=\left\{\begin{array}{c}
A_{1} \sigma_{\mathrm{p}}^{n}\left(\alpha \sigma_{\mathrm{p}}<0.8\right. \\
A_{2} \exp \left(\beta \sigma_{\mathrm{p}}\right)\left(\alpha \sigma_{\mathrm{p}}>1.2\right) \\
A\left[\sinh \left(\alpha \sigma_{\mathrm{p}}\right)\right]^{n_{1}}
\end{array}\right.
$$

Here, $\dot{\varepsilon}$ is the strain rate. $A, A_{1}$ and $A_{2}$ are the material constants independent of the temperature. $Q$ is the hotdeformation activation energy. $R$ is the gas constant. $T$ is the absolute temperature of deformation. $\sigma_{\mathrm{p}}$ is the peak stress. $\alpha(\alpha=\beta / n)$ and $n_{1}$ are the constants.

By taking the logarithm of both sides, Equation (1) becomes:

$$
\ln Z=\ln \dot{\varepsilon}+\frac{Q}{R T}=\left\{\begin{array}{c}
\ln A_{1}+n \ln \sigma_{\mathrm{p}}\left(\alpha \sigma_{\mathrm{p}}<0.8\right. \\
\ln A_{2}+\beta \sigma_{\mathrm{p}}\left(\alpha \sigma_{\mathrm{p}}>1.2\right) \\
\ln A+n_{1} \ln \left[\sinh \left(\alpha \sigma_{\mathrm{p}}\right)\right]
\end{array}\right.
$$
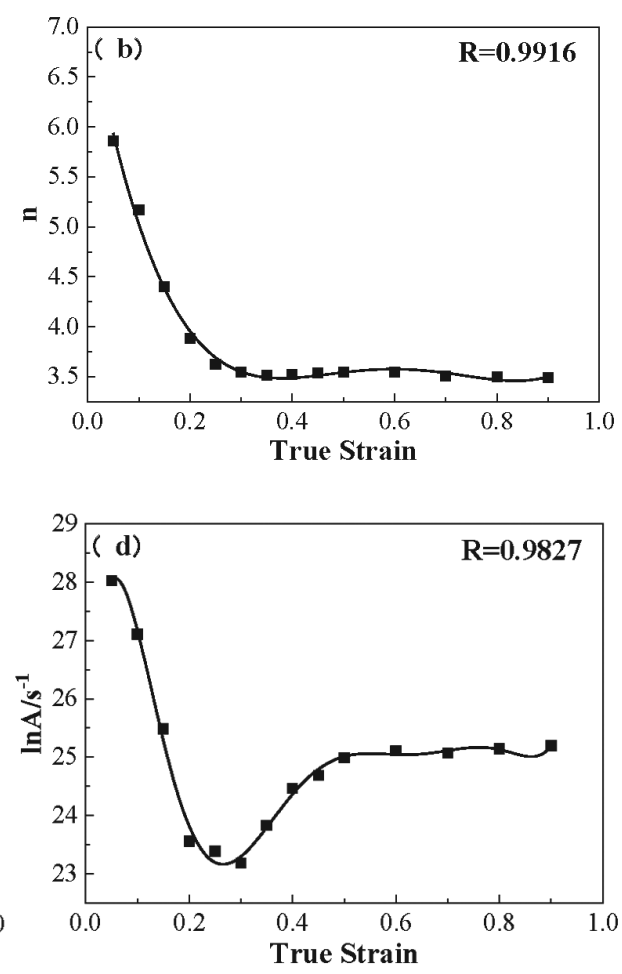

Figure 2: Variations of material constants of: a) $\alpha$, b) $n$, c) $Q$ and d) $\ln A$ with strain 


\section{L.-Y. YE et al.: MODELING AND SIMULATION BASED ON THE CONSTITUTIVE EQUATION OF 25Cr2Ni4MoV STEEL ...}

Stress exponent $n$ can be calculated from the slope of $\ln \dot{\varepsilon}$ versus $\ln \sigma_{\mathrm{p}}$. Constant $\beta$ is the slope of $\ln \dot{\varepsilon}$ versus $\sigma_{\mathrm{p}}$ $n_{1}$ is the slope of $\ln \dot{\varepsilon}$ versus $\ln \left(\sinh \left(\alpha \sigma_{\mathrm{p}}\right)\right.$. $\ln A$ can be calculated from the intercept of $\ln Z$ versus $\ln \left(\sinh \left(\alpha \sigma_{\mathrm{p}}\right)\right.$.

Table 2: Coefficients of the $8^{\text {th }}$-order polynomial function for $\alpha, n, Q$, $\ln A$

\begin{tabular}{|c|c|c|c|}
\hline$\alpha$ & $n$ & $Q$ & $\ln A$ \\
\hline 0.04463 & 7.17284 & 333377.48 & 24.64146 \\
\hline-0.34769 & -28.40935 & $2.27008 \mathrm{E} 6$ & 142.70483 \\
\hline 3.11804 & 78.24198 & $-2.78735 \mathrm{E} 7$ & -1930.30145 \\
\hline-15.31759 & -90.63266 & $1.36559 \mathrm{E} 8$ & 9676.35721 \\
\hline 46.09771 & 37.47988 & $-3.37958 \mathrm{E} 8$ & -24041.8169 \\
\hline-86.77108 & 0 & $4.50276 \mathrm{E} 8$ & 31935.3452 \\
\hline 98.89885 & 0 & $-3.08756 \mathrm{E} 8$ & -21769.95705 \\
\hline-62.01835 & 0 & $8.56192 \mathrm{E} 7$ & 5994.97466 \\
\hline 16.34468 & 0 & 0 & 0 \\
\hline
\end{tabular}

The Arrhenius model mentioned above does not consider the influence of the strain. However, by taking the same solution process as explained with Equations (1) and (2), different material constants $(\alpha, n, Q, \ln A)$ were obtained at different strains. ${ }^{14-16}$ Hence, the straincompensated Arrhenius-type constitutive model is applied to describe the flow stress, assuming that the material constants $(\alpha, n, Q, \ln A)$ are the polynomial functions of the strains. The flow curves with strain rates of $(0.001,0.005,0.01$ and 0.1$) \mathrm{s}^{-1}$ are used to calculate the strain-compensated Arrhenius model. The relationships between the material constants and strains of $25 \mathrm{Cr} 2 \mathrm{Ni} 4 \mathrm{MoV}$ are shown in Figure 2. Using the poly-
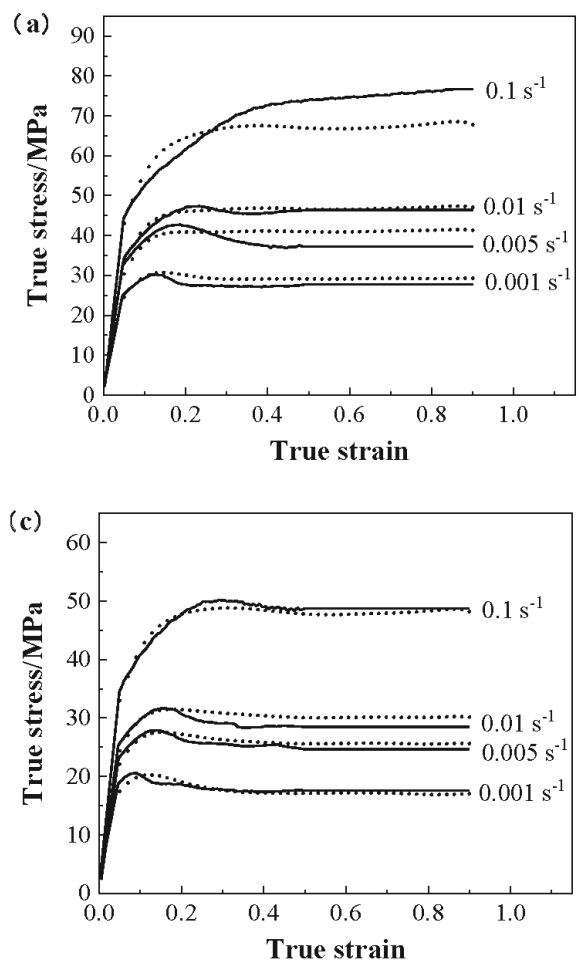

nomial fitting, the constitutive equations are obtained as given in Equation (3). The coefficients of the eighthorder polynomial are listed in Table 2 .

$n=n_{0}+n_{1} \varepsilon+n_{2} \varepsilon^{2}+n_{3} \varepsilon^{3}+n_{4} \varepsilon^{4}+n_{5} \varepsilon^{5}+n_{6} \varepsilon^{6}+n_{7} \varepsilon^{7}+n_{8} \varepsilon^{8}$
$\alpha=\alpha_{0}+\alpha_{1} \varepsilon+\alpha_{2} \varepsilon^{2}+\alpha_{3} \varepsilon^{3}+\alpha_{4} \varepsilon^{4}+\alpha_{5} \varepsilon^{5}+\alpha_{6} \varepsilon^{6}+\alpha_{7} \varepsilon^{7}+\alpha_{8} \varepsilon^{8}$
$Q=Q_{0}+Q_{1} \varepsilon+Q_{2} \varepsilon^{2}+Q_{3} \varepsilon^{3}+Q_{4} \varepsilon^{4}+Q_{5} \varepsilon^{5}+Q_{6} \varepsilon^{6}+Q_{7} \varepsilon^{7}+Q_{8} \varepsilon^{8}$
$\ln A=A_{0}+A_{1} \varepsilon+A_{2} \varepsilon^{2}+A_{3} \varepsilon^{3}+A_{4} \varepsilon^{4}+A_{5} \varepsilon^{5}+A_{6} \varepsilon^{6}+A_{7} \varepsilon^{7}+A_{8} \varepsilon^{8}$

\subsubsection{Prediction of stress-strain curves}

Theoretical values and the experimental values at different strains are shown in Figure 3. It can be seen that the theoretical results show good agreement with the experimental results. In order to quantitatively evaluate the accuracy of the developed constitutive model, the correlation coefficient $(R)$ and average absolute relative error (AARE) are calculated with the expressions below.

$$
\begin{gathered}
R=\frac{\sum_{i=1}^{n}\left(P_{i}-\bar{P}\right)\left(E_{i}-\bar{E}\right)}{\sqrt{\sum_{i=1}^{n}\left(P_{i}-\bar{P}\right)^{2} \sum_{i=1}^{n}\left(E_{i}-\bar{E}\right)^{2}}} \\
A A R E=\frac{100 \%}{n} \sum_{i=1}^{n}\left|\frac{\left(P_{i}-E_{i}\right)}{E_{i}}\right|
\end{gathered}
$$

Here, $P_{i}$ is the predicted value and $\bar{P}$ is the mean value of $P_{i} . E_{i}$ is the experimental value and $\bar{E}$ is the mean value of $E_{i} . n$ is the number of data employed in the investigation. The strain range is from 0.05 to 0.5 with an interval of 0.05 and from 0.5 to 0.9 with an interval of 0.1 . A comparison of the predicted values and experimental results for all the deformation conditions is
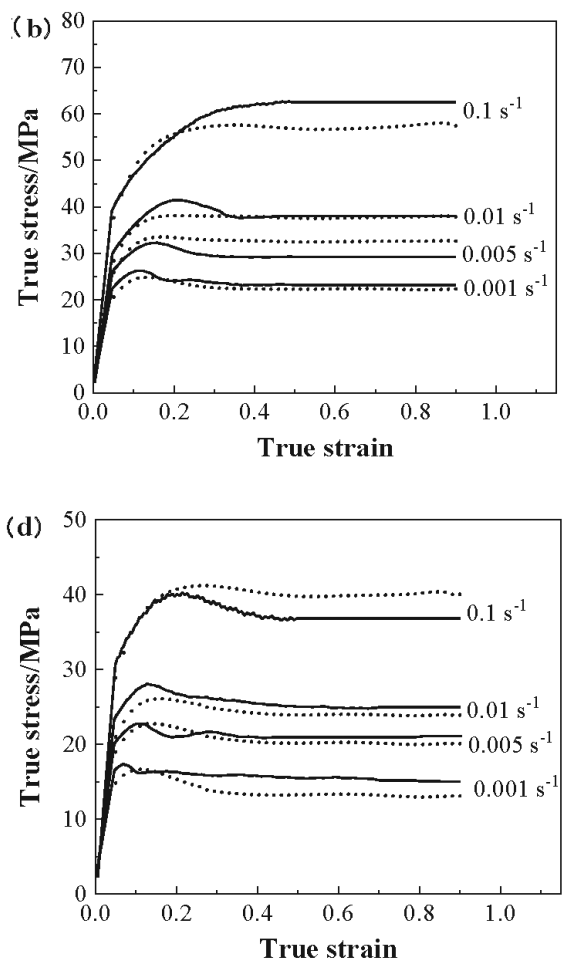

Figure 3: Comparison of the experimental and predicted flow stress at different temperatures: a) $1373 \mathrm{~K}$, b) $1423 \mathrm{~K}$, c) $1473 \mathrm{~K}$, d) $1523 \mathrm{~K}$ 


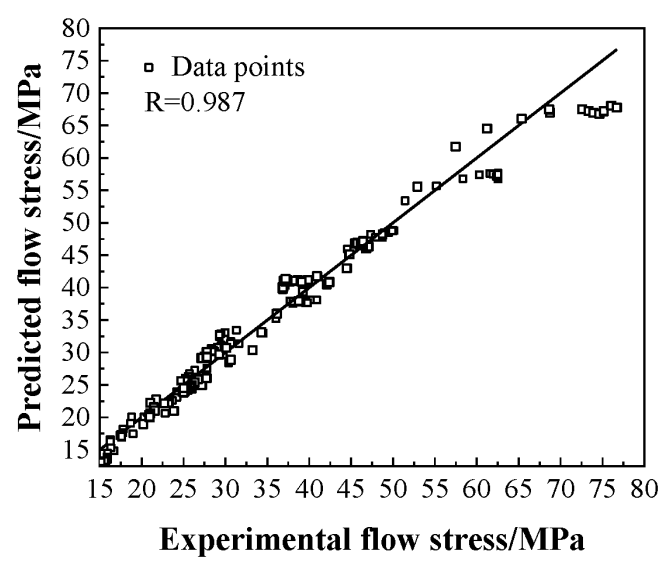

Figure 4: Correlation between the experimental and predicted flowstress data

shown in Figure 4. It should be mentioned that the maximum average absolute relative error is $6.7 \%$ at the deformation conditions including a temperature of $1373 \mathrm{~K}$ and a strain rate of $0.1 \mathrm{~s}^{-1}$. This is because the flow-stress curve of this deformation condition does not show the single peak of dynamic recrystallization, while the other flow curves do. The correlation coefficient $(R)$ of all the deformation conditions is 0.987 and the average absolute relative error (AARE) is $5.18 \%$, showing that the constitutive model has a good predictability of the flow stress for the $25 \mathrm{Cr} 2 \mathrm{Ni} 4 \mathrm{MoV}$ steel.

\subsection{Comparison of the Arrhenius model and linear- interpolation method}

As the strain-compensated Arrhenius model is not provided by the FE software, the tabular-data format or user-defined flow-stress subroutine can be used to input the flow curves. The method of the tabular-data format allows the calculation of the flow curves at different deformation conditions using linear interpolation based on the data table. For example, for a certain deformation temperature, $\sigma_{0.1}$ and $\sigma_{0.01}$ represent the flow stress at strain rates of $0.1 \mathrm{~s}^{-1}$ and $0.01 \mathrm{~s}^{-1}$, respectively. According to the linear interpolation, 0.05 equals 0.556 times 0.001 plus 0.444 times 0.1 . Hence, to compute the flow stress at a strain rate of $0.05 \mathrm{~s}^{-1}$ at a certain temperature, Equation (6) is employed using linear interpolation. ${ }^{17}$

$$
\sigma_{0.05}=0.556 \sigma_{0.01}+0.444 \sigma_{0.1}
$$

Figure 5 shows the comparison of the flow stress predicted by the strain-compensated Arrhenius model and the linear-interpolation method at the strain rate of $0.05 \mathrm{~s}^{-1}$. It is obvious that the strain-compensated Arrhenius model is much better for predicting the flow stress than the linear-interpolation method, especially when predicting a flow stress lower than the peak stress. The average absolute relative errors (AARE) for the Arrhenius model and linear-interpolation method are $3.62 \%$ and $7.55 \%$, respectively. The correlation coefficients $(R)$ for the Arrhenius model and interpolation-linear method are 0.9890 and 0.9806 , respectively. Therefore, consider-

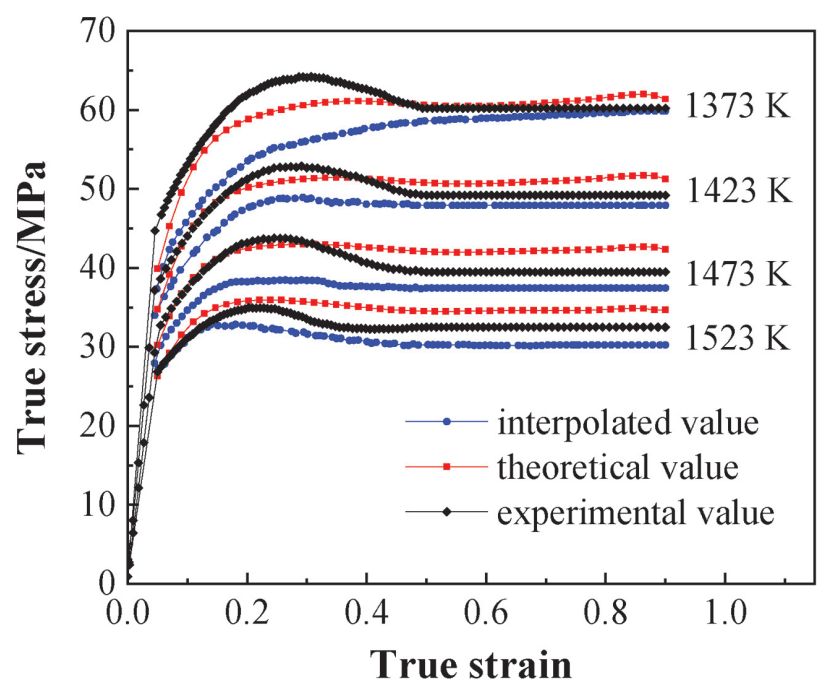

Figure 5: Comparison of the experimental and predicted flow stress at the strain rate of $0.05 \mathrm{~s}^{-1}$ with different temperatures: a) $1373 \mathrm{~K}$, b) $1423 \mathrm{~K}$, c) $1473 \mathrm{~K}$, d) $1523 \mathrm{~K}$

ing the application of flow curves in the FE simulation for the $25 \mathrm{Cr} 2 \mathrm{Ni} 4 \mathrm{MoV}$ steel, inserting the strain-compensated Arrhenius model into the FE software with the user-defined flow-stress subroutine should be chosen as the more accurate method than the linear-interpolation method.

\subsection{FE simulation and verification}

To apply the constitutive equation to the numerical simulation, a FEM code was developed based on the constitutive model to simulate the isothermal compression with FE software DEFORM. The geometry model of the workpiece was the same as the compression test mentioned above. The die velocity was $0.1 \mathrm{~mm} / \mathrm{s}$ and $0.5 \mathrm{~mm} / \mathrm{s}$ and the friction factor was 0.3 . The tracking of the values of the effective strain, effective strain rate and effective stress at the center of the workpiece during the isothermal compression is shown in Figure 6. Figure 7 shows that at the deformation condition of $1373 \mathrm{~K}-$ $0.1 \mathrm{~mm} / \mathrm{s}$ with a die stroke of $5.4 \mathrm{~mm}$, the effective strain, effective strain rate and effective stress at the center of the workpiece are $0.874,0.0226 \mathrm{~s}^{-1}$ and

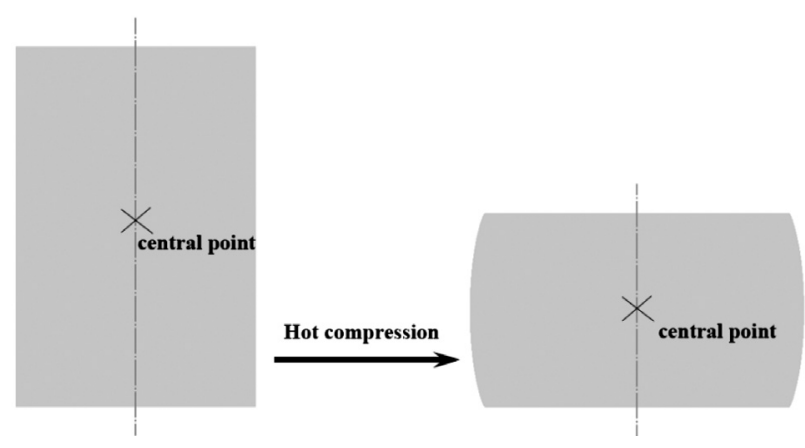

Figure 6: Tracking point 

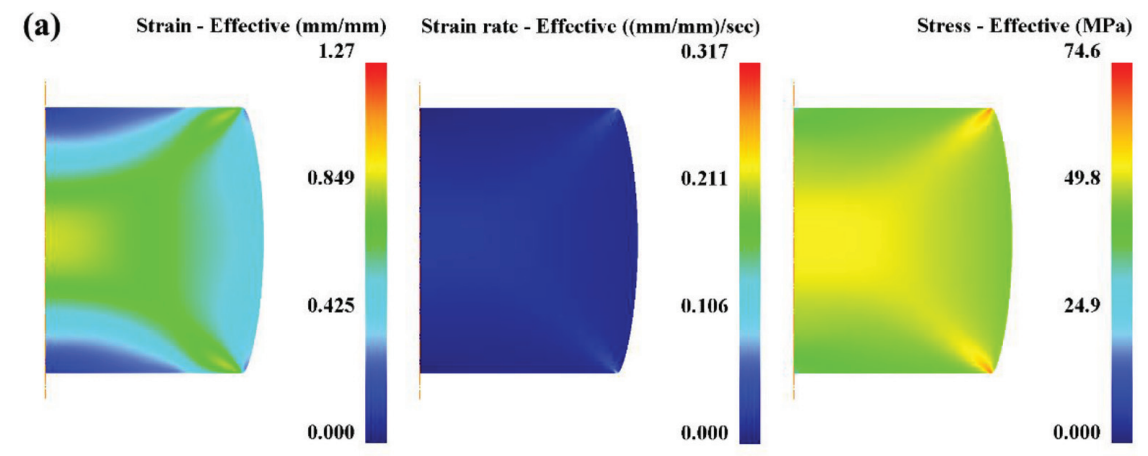

(b)
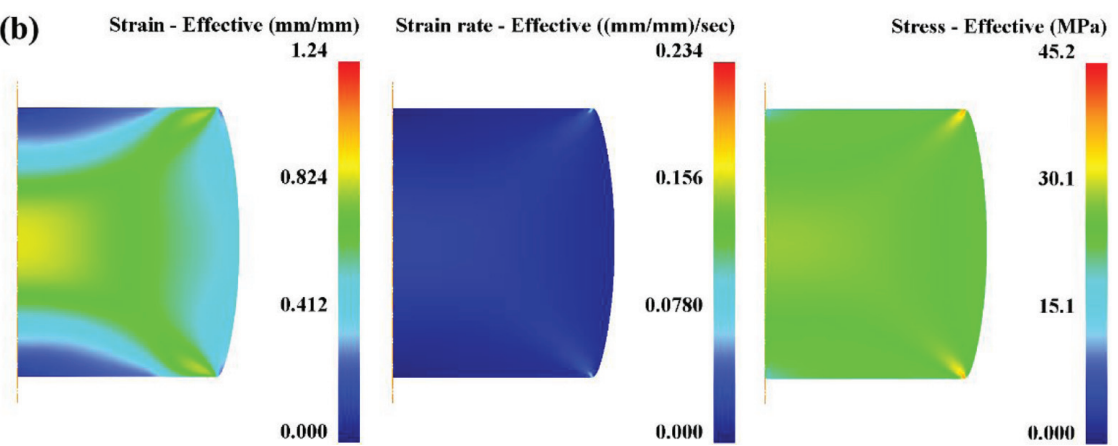

Figure 7: Distribution of effective strain, effective strain rate and effective stress at a die stroke of $5.4 \mathrm{~mm}$ : a) $1373 \mathrm{~K}-0.1 \mathrm{~mm} / \mathrm{s}, \mathrm{b}) 1523 \mathrm{~K}-0.1$ $\mathrm{mm} / \mathrm{s}$

54.6 $\mathrm{MPa}$, respectively. At the deformation condition of $1523 \mathrm{~K}-0.1 \mathrm{~mm} / \mathrm{s}$ with a die stroke of $5.4 \mathrm{~mm}$, the effective strain, effective strain rate and effective stress are $0.865,0.0227 \mathrm{~s}^{-1}$ and $29.2 \mathrm{MPa}$, respectively. The comparison between the theoretical results and simulated results is given in Figure 8. It can be seen that the theoretical values are nearly equal to the simulated values with a stress range of 17-70 $\mathrm{MPa}$. The average absolute relative error (AARE) of the simulated and theoretical results is $0.046 \%$. The theoretical results show good agreement with the experimental results, as stated above. Hence, it can be deduced that the simulated results predict well the flow behavior of the $25 \mathrm{Cr} 2 \mathrm{Ni} 4 \mathrm{MoV}$ steel.

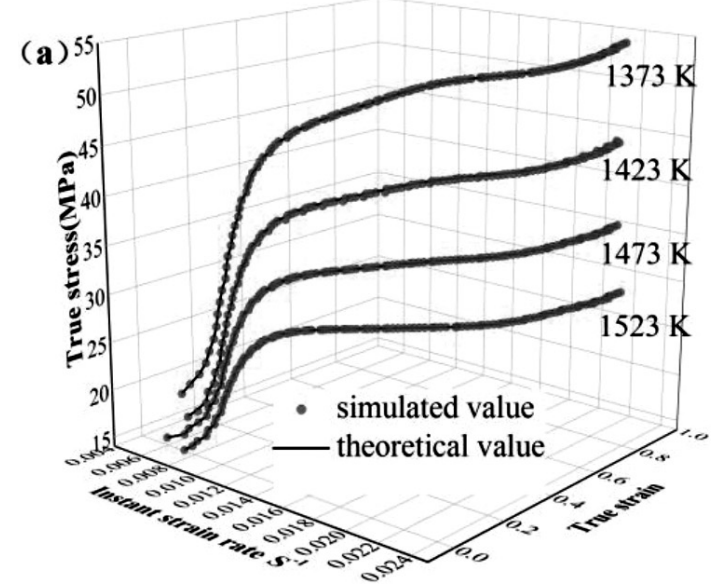

\section{CONCLUSIONS}

To perform a simulation of a forging process for the $25 \mathrm{Cr} 2 \mathrm{Ni} 4 \mathrm{MoV}$ steel, a set of compression tests was carried out to investigate the flow behavior of the $25 \mathrm{Cr} 2 \mathrm{Ni} 4 \mathrm{MoV}$ steel. Conclusions were obtained as follows:

- An Arrhenius model considering the influence of the strain was established to describe the flow stress. The comparison between the experimental result and theoretical result indicates that the strain-compensated Arrhenius model predicts the flow behavior of the material well.

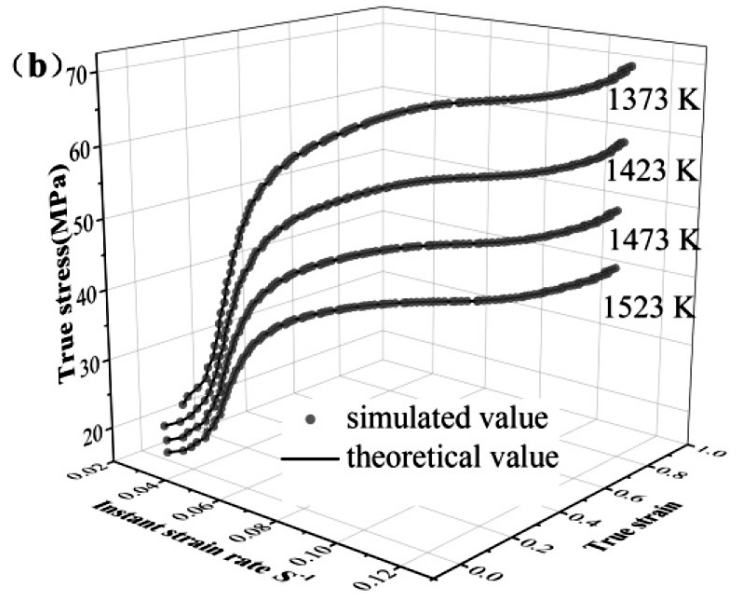

Figure 8: Comparison between the simulated and theoretical flow stress at different die velocities: a) $0.1 \mathrm{~mm} / \mathrm{s}$, b) $0.5 \mathrm{~mm} / \mathrm{s}$ 
- The strain-compensated Arrhenius model and linear-interpolation method were used to predict the flow stress at a strain rate of $0.05 \mathrm{~s}^{-1}$. The average absolute relative errors (AARE) for the Arrhenius model and linear-interpolation method were $3.62 \%$ and $7.55 \%$, respectively. Hence, the strain-compensated Arrhenius model is more accurate than the linear-interpolation method.

- The application of the strain-compensated Arrhenius model in FE software DEFORM with a user-defined material subroutine confirms that the developed model is capable of predicting the flow stress and utilizing in the FE simulation software.

- The above research results provide an important basis for forging simulations involving the $25 \mathrm{Cr} 2 \mathrm{Ni} 4 \mathrm{MoV}$ steel for super-large nuclear-power rotors.

\section{Acknowledgement}

The authors appreciate the financial support from the National Science and Technology Major Project of China (Grant No. 2018ZX04044001).

\section{REFERENCES}

${ }^{1}$ F. Chen, F. C. Ren, Z. S. Cui, Constitutive modeling for elevated temperature flow behavior of $30 \mathrm{Cr} 2 \mathrm{Ni} 4 \mathrm{MoV}$ ultra-super-critical rotor steel, Journal of Iron and Steel Research International, 21 (2014) 5, 521-526, doi:10.1016/S1006-706X(14)60081-9

${ }^{2}$ L. J. Tan, J. Q. Wang, Q. Q. Wang, Microstructure and mechanical properties of $25 \mathrm{Cr} 2 \mathrm{Ni} 4 \mathrm{MoV}$ steel large forgings, Heat Treatment of Metals, 39 (2014) 1, 128-131, doi:10.13251/j.issn.02546051.2014.01.026

${ }^{3}$ S. J. Li, M. Y. Sun, H. W. Liu, D. Z. Li, Study on void healing behavior during forging process for $25 \mathrm{Cr} 2 \mathrm{Ni} 4 \mathrm{MoV}$ steel, Acta Metallurgica Sinica, 47 (2011) 7, 946-953, doi:10.3724/SP.J. 1037.2011 .00157

${ }^{4}$ Q. Y. Wang, Q. L. Feng, Y. W. Niu, Study on technology of heat treatment after forging for roll shaft of $25 \mathrm{Cr} 2 \mathrm{Ni} 4 \mathrm{MoV}$ steel, Heat Treatment Technology and Equipment, 36 (2015) 3, 24-27, doi:10.19382/j.cnki.1673-4971.2015.03.006

${ }^{5}$ S. Solhjoo, A. I. Vakis, Y. T. Pei, Two phenomenological models to predict the single peak flow stress curves up to the peak during hot deformation, Mechanics of Materials, 105 (2017), 61-66, doi:10.1016/j.mechmat.2016.12.001

${ }^{6}$ L. Xu, L. Chen, G. J. Chen, M. Q. Wang, Hot deformation behavior and microstructure analysis of $25 \mathrm{Cr} 3 \mathrm{Mo} 3 \mathrm{NiNb}$ steel during hot compression tests, Vacuum, 147 (2018), 8-17, doi:10.1016/ j.vacuum.2017.10.017

${ }^{7}$ Y. Zhang, H. L. Sun, A. A. Volinsky, B. H. Tian, Hot workability and constitutive model of the $\mathrm{Cu}-\mathrm{Zr}-\mathrm{Nd}$ alloy, Vacuum, 146 (2017), 35-43, doi:10.1016/j.vac-uum.2017.09.017

${ }^{8}$ L. Chen, G. Q. Zhao, J. Q. Yu, W. D. Zhang, Constitutive analysis of homogenized 7005 aluminum alloy at evaluated temperature for extrusion process, Materials and Design, 66 (2015), 129-136, doi:10.1016/j.matdes.2014.10.045

${ }^{9}$ Y. F. Li, Z. H. Wang, L. Y. Zhang, C. Luo, X. C. Lai, Arrhenius-type constitutive model and dynamic recrystallization behavior of V-5Cr-5Ti alloy during hot compression, Transactions of Nonferrous Metals Society of China, 25 (2015), 1889-1900, doi:10.1016/ S1003-6326(15)63796-7

${ }^{10}$ A. Abbasi Bani, A. Zarei Hanzaki, M. H. Pishbin, N. Haghdadi, A comparative study on the capability of Johnson-Cook and Arrhenius-type constitutive equations to describe the flow behavior of Mg-6Al-1Zn alloy, Mechanics of Materials, 71 (2014), 52-61, doi:10.1016/j.mechmat.2013.12.001

${ }^{11}$ C. M. Sellars, W. J. Mctegart, On the mechanism of hot deformation, Acta Metallurgica, 14 (1966), 1136-1138, doi:10.1016/0001-6160 (66)90207-0

${ }^{12}$ H. Mirzadeh, J. M. Cabrera, J. M. Prado, Hot deformation behavior of a medium carbon microalloyed steel, Materials Science and Engineering A, 528 (2011), 3876-3882, doi:10.1016/j.msea.2011. 01.098

${ }^{13}$ C. Zener, J. H. Hollomon, Effect of strain rate upon plastic flow of steel, Journal of Applied Physics, 15 (1944), 22-32, doi:10.1063/ 1.1707363

${ }^{14}$ Y. C. Lin, M. S. Chen, J. Zhang, Modeling of flow stress of 42CrMo steel under hot compression, Materials Science and Engineering A, 499 (2009), 88-92, doi:10.1016/j.msea.2007.11.119

${ }^{15}$ S. Mandal, V. Rakesh, P. V. Sivaprasad, Constitutive equations to predict high temperature flow stress in a Ti-modified austenitic stainless steel, Materials Science and Engineering A, 500 (2009), 114-121, doi:10.1016/j.msea.2008.09.019

${ }^{16}$ D. Samantaray, S. Mandal, A. K. Bhaduri, Constitutive analysis to predict high-temperature flow stress in modified $9 \mathrm{Cr}-1 \mathrm{Mo}(\mathrm{P} 91)$ steel, Materials and Design, 31 (2010), 981-984, doi:10.1016/ j.matdes.2009.08.012

${ }^{17}$ Q. Y. Li, N. C. Wang, D. Y. Yi, Numerical analysis, $4^{\text {th }}$ ed., Tsinghua University Press, Beijing 2001, 21-23 